\title{
SONOR DAN BIAS “CETAK SAWAH” DI LAHAN GAMBUT
}

\author{
Sonor and Bias of "Cetak Sawah" on Peat Land
}

\author{
Ciptaningrat Larastiti \\ Samadhya Institute, Yogyakarta \\ https://samadhya.org/ dan ciptahningrat@gmail.com
}

\begin{abstract}
Peat land has been intensively known as the target of creating idle land through state owned forest mechanism. It triggers a large scale development project such as an irrigated rice field called "Cetak Sawah". By focusing on "Cetak Sawah", we can learn how development project contains an inherent assumption of modern field rice system to overcome massive deteriorated peat land particularly since the forest fire disaster in 2015. The research was done a year after forest fire 2015 through an ethnographic method consisted of live in and several visits around February 2016-December 2016. The gathered data show that "Cetak Sawah" becomes the technocratic approach of peat land governance. Instead of controlling the expansion of palm oil industry, state has been continually blamed the former agricultural system known as Sonor (swidden agriculture) which will be easily considered as the main factor of undermined peat ecosystem due to its burning practice of land preparation. There are two gaps, first, "Cetak Sawah" has been proposed through negation of existing social differentiation. Second, "Cetak Sawah" is going to be predicted as the mean of peasant exclusion.
\end{abstract}

Key words: Peat land, Cetak Sawah, development bias, swidden cultivation, sonor, ecological social dynamic.

Intisari: Lahan gambut telah secara luas dikenal sebagai target menciptakan tanah terlantar melalui mekanisme hutan Negara. Hal ini memancing pembangunan proyek skala besar seperti sawah irigasi yang juga disebut sebagai “Cetak Sawah". Dengan berfokus pada Cetak Sawah", kita dapat belajar bagaimana proyek pembangunan dapat mengandung asumsi yang tak terpisahkan dari sistem tanam padi modern untuk mengatasi lahan gambut yang semakin memburuk secara luas terutama sejak bencana kebakaran hutan di tahun 2015. Penelitian ini dilakukan setahun setelah kebakaran hutan tahun 2015 melalui metode etnografi yang terdiri dari laporan langsung dan beberapa kunjungan pada kurun Februari 2016 - Desember 2016. Data yang dikumpulkan menunjukkan bahwa "Cetak Sawah" menjadi pendekatan teknokratis untuk pengelolaan lahan gambut. Di samping mengontrol ekspansi industri kelapa sawit, Negara juga terus menyalahkan pertanian lahan berpindah yang sering dikenal sebagai Sonor, yang sering disebut sebagai faktor utama dari rusaknya ekosistem gambut sehubungan dengan praktik pembakaran hutan. Ada dua gap yang diungkapkan, pertama, Cetak Sawah telah diusulkan menjadi negasi dari diferensiasi sosial yang sudah ada. Kedua, Cetak Sawah telah diprediksi sebagai alat untuk mengeksklusi petani.

Kata Kunci: lahan gambut, cetak sawah, bias pembangunan, perladangan sonor, dinamika sosial ekologis. 


\section{A. Pendahuluan}

Sejak masa kolonial, menurut Peluso dan Vandergeest (2001 dan 2006) serta Potter (1988), ${ }^{1}$ ekosistem gambut merupakan target pengaturan ruang seiring diciptakannya gagasan tentang lahan terlantar dan lahan tidak produktif. Hal ini memobilisasi jutaan Hektare lahan gambut menjadi kawasan hutan -lantas dikenal sebagai domain tanah negara

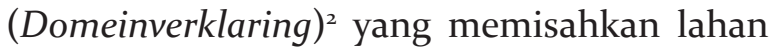
budidaya sebagai tanah hak dan lahan terlantar sebagai tanah negara. Melalui peraturan inilah, pemerintah memiliki kewenangan terhadap ekosistem gambut untuk diberi ragam konsesi dan proyek-proyek pembangunan. Bila demikian, kita perlu mencermati proyek pembangunan terutama yang berbasis lahan skala luas tanpa terkecuali Proyek Cetak Sawah. Proyek ini menyimpan asumsi tentang sistem produksi pertanian sawah sebagai jalan keluar bagi perbaikan ekosistem gambut yang kian memburuk. Sementara sistem perladangan dengan cara membakar, seperti Sonor, menjadi praktik tidak ramah lingkungan meski telah dilakukan secara turun temurun.

1 Ketiganya memberikan contoh tentang dinamika sosial dan ekologis dari proses pengaturan teritori di ekosistem gambut Kalimantan. Potter (1988) menyebutnya sebagai South Centre Borneo yang dulunya menjadi kawasan Kesultanan Banjarmasin dan Dayak Ngaju lantas diberikan kepada Dutch Borneo. Sementara Vandergeest dan Peluso (2001) banyak bekerja di Kalimantan Barat tepatnya di kawasan ekosistem gambut Danau Sentarum.

2 Tauchid (2009, 23) menjelaskan bahwa Domeinverklaring lahir sejak 9 April 1870 pada saat pemerintah Hindia Belanda menerbitkan Agrarische Wet (biasa dikatakan wet de Waal) dan kemudian lahir Agraris Besluit ... yang memuat pernyataan hak negeri atas tanah. Domeinverklaring melahirkan bermacammacam undang-undang pertanahan di Indonesia untuk kepentingan menjamin modal partikelir terutama modal partikelir Belanda. Domeinverklaring termuat dalam pasal 1 dari Agraris Besluit (Stbl. 1870 No. 118), berbunyi: "Semua tanah yang tidak dimiliki hak eigendom (hak properti pribadi), adalah kepunyaan Negeri”.
Kata Sonor sendiri berasal dari proses penyiapan lahan pertanian yang didahului pembakaran permukaan gambut. Gambut yang terbakar menjadi unsur hara penting bagi padi lokal untuk tumbuh. Dengan melakukan Sonor, curahan kerja petani untuk menyiapkan lahan menjadi lebih sedikit. Perladangan Sonor juga dilakukan di atas lahan bertanah mineral. Bedanya, bila benih padi disebardi lahan gambut, maka benih di lahan mineral akan ditanam di lubang kecil dalam tanah. Proses perladangan di atas tanah mineral memakan banyak waktu dan menyerap tenaga kerja dalam jumlah besar dibandingkan di lahan gambut. Perlahan, sistem perladangan di atas tanah mineral pun mudah tergantikan komoditas karet yang datang seiring kolonisasi Belanda pada awal abad 20. Karet menjadi penanda penting bagi perubahan produksi petani yang didasari kepemilikan lahan dan pasar komoditas.

Di samping karet, ledakan komoditas kayu juga menjadi pendorong utama bagi perekonomian uang tunai di kampung. Pada 1979-1984, tercatat 20.00o Hektare lahan gambut diberikan kepada perusahaan swasta berijin hak pengusahaan hutan (HPH). Perusahaan ini membuka aktivitas penebangan kayu ramin (gonystylus bancanus) dan meranti (shorea) yang menjadi endemik kawasan gambut. Saat harga karet dan kayu membaik, perladangan Sonor berubah menjadi pelengkap semata. Bahkan sebagian rumah tangga tani memenuhi konsumsi pokok dengan membeli. Lambat laun, perekonomian petani Talang lebih banyak ditentukan oleh fluktuasi harga komoditas ekspor. Saat logging kayu dilarang pada 2004 dan harga karet merosot sejak 2010, perladangan Sonor menjadi pilihan penting untuk menutup kebutuhan beras di dapur. Hanya saja, lahan gambut yang dianggap daerah terlantar menjadi mudah dialihkuasakan kepada investasi perkebunan selama otonomi daerah. Gambut mewujud sebagai arena politik yang 
pemanfaatannya tidak hanya ditentukan petani penggarap, melainkan teknokrasi pemerintah daerah dan pemerintah pusat terhadap investasi komoditas ekspor seperti perkebunan sawit.

Pada 2005, komunitas tani Desa Talang berhadapan dengan tentara untuk memperebutkan wilayah perladangan sonor yang diklaim konsesi perkebunan sawit PT Persada Sawit Mas dan PT Bumi Andalas Permai. PT Persada Sawit Mas mendaku lahan seluas 45.0oo Hektare, sementara PT Bumi Andalas Permai menklaim lahan 4.000 Hektare dimana 700 Hektare di antaranya merupakan lahan garapan warga untuk perladangan Sonor. Perlawanan petani ini membuahkan hasil dengan didapatkannya wilayah kelola warga seluas 5.50o Hektare pada 2008. Konflik lahan yang berlangsung 20052008 ini pun melahirkan gabungan kelompok tani (Gapoktan Bersatu Maju) Desa Talang yang diharapkan mampu mengurus wilayah perladangan Sonor. Salah satu inisiatifnya ialah pembangunan kanal swadaya sepanjang 20 kilometer sebagai tanda hak kelola warga.

\section{Gambar 1. Wilayah Kelola Desa Talang}

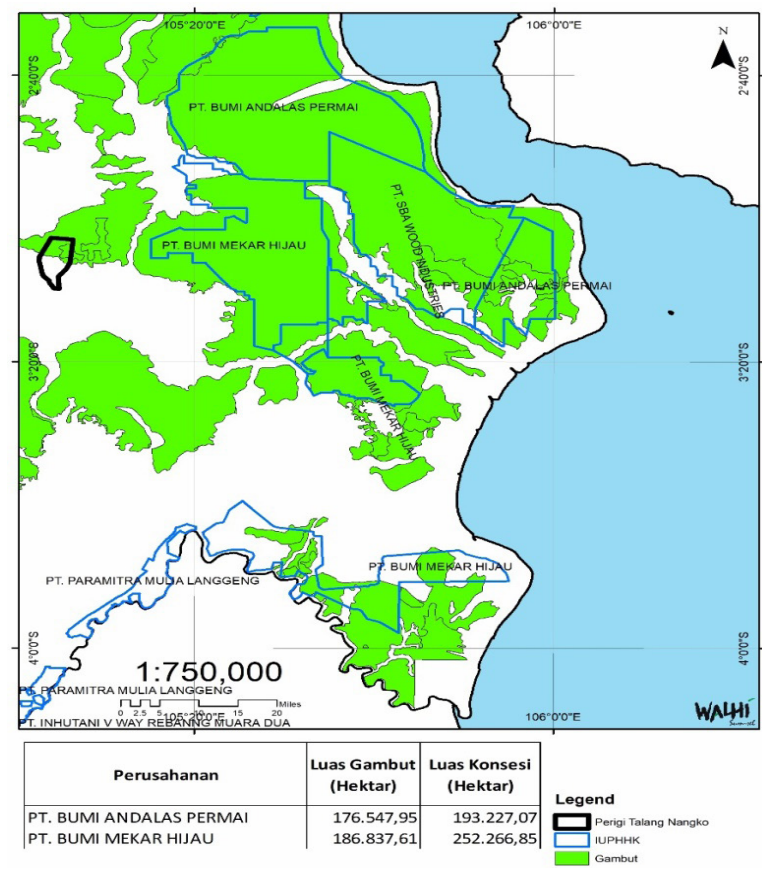

Sumber: WALHI Sumatera Selatan

\section{Keterangan}

Dari peta di samping, garis warna hitam merupakan wilayah kelola Desa Talang. Lokasi ini, dikepung oleh konsesi hutan tanaman industri di sisi timurnya, antara lain PT Bumi Mekar Hijau, dan PT SBA Wood Industries. Serta PT Bumi Andalas Permai, yang merupakan perkebunan kelapa sawit anak perusahaan PT Sinar Mas Group. Sementara di sisi barat, terdapat konsesi perkebunan kelapa sawit antara lain PT Persada Sawit Mas (tidak terlihat di peta), dan di sisi utara ada Suaka Margasatwa Padang Air Sugihan (tidak terlihat di peta). PT Bumi Mekar Hijau sendiri dikenal sebagai pelaku tindak pidana pembakaran hutan 2015 yang digugat 7,9 trilliun kerugian negara oleh Kementerian Lingkungan Hidup dan Kehutanan. Namun, anak perusahaan PT Asian Pulp and Papper ini diputuskan tidak bersalah oleh Pengadilan Tinggi Palembang pada 12 Agustus 2016 dan hanya membayar 78 miliar saja. ${ }^{3}$

Sejak harga karet jatuh di bawah harga beras beberapa tahun belakangan, ${ }^{4}$ petani Talang pun mengandalkan pemenuhan makanan pokok dengan menggarap ladang Sonor. Namun, proses penyiapan lahan dengan cara membakar membuat sistem perladangan ini dilematis. Pada 2015, saat kebakaran hutan di Sumatera Selatan terjadi, pembakaran lahan melalui Sonor disalahkan sebagai penyebab kebakaran. Munculnya titik api di Sumatera

3 https://bisnis.tempo.co/read/800226/ kebakaran-hutan-pt-bumi-mekar-hijaucuma-bayar-rp-78-miliar diakses pada 13 November 2017

4 "Harga karet yang sejak tahun lalu (2015 red-) terus turun kini berkisar Rp 4.000 - Rp 6.000 per kilogram. Anjloknya harga karet tersebut membuat petani karet menjerit akibat harga tersebut jauh di bawah harga beras yang saat ini berkisar Rp1o.ooo/kilogram, ... ” bagian ini dikutip dari artikel berita oline berikut http:// nasional.republika.co.id/berita/nasional/ daerah/16/o3/15/o436zv361-harga-karetanjlok-petani-sumsel-menjerit diakses pada 31 Oktober 2017 
Selatan pada $2015^{5}$ tidak dilihat sebagai konsekuensi atas penerbitan ijin konsesi hutan tanaman industri maupun perkebunan sawit. Sebagai tindakan preventif, Pemerintah Provinsi Sumatera Selatan justru menerbitkan Peraturan Daerah No 8 Tahun 2016 yang melarang pembakaran hutan oleh perorangan seperti perladangan Sonor. ${ }^{6}$ Peraturan ini menjadi ancaman petani penggarap untuk terus menanam padi di tengah harga karet yang tak mampu memenuhi kebutuhan pangan keluarga. Kondisi ini berujung pada usulan Proyek Cetak Sawah awal 2016 oleh Gapoktan Bersatu Maju Desa Talang. Harapannya, proyek tersebut mampu menjawab kebutuhan subsistensi rumah tangga tani yang tidak mampu dipenuhi dari penjualan karet.

Sebagai inisiasi pembangunan, Proyek Cetak Sawah hadir dalam paket kebijakan teknokratis untuk perlindungan lahan pangan dan restorasi gambut. Namun, proyek yang diharapkan mampu menjawab pelarangan pembakaran lahan ini justru menjadi tanda

5 "Data Badan Nasional Penanggulangan Bencana (BNPB), pada Kamis 27 Agustus 2016, menunjukkan ada 178 titik api tersebar di Sumatera. Sebagian besar berada di Sumatera Selatan dengan 8o titik api, dan Jambi dengan 69 titik api. Lainnya, ada 10 titik api di Bangka Belitung dan lima titik api di Riau." http://www.bbc.com/indonesia/berita indonesia/2015/08/150827_indonesia_jambi_titikapi diakses pada pada 8 November 2017

6 Pada ayat 1 dan 2 pasal 5 Perda No. 8/2016 disebutkan bahwa masyarakat di sekitar hutan atau lahan rawan kebakaran wajib selalu siaga dan ikut serta dalam pencegahan dan penanggulangan kebakaran hutan dan lahan, secara perseorangan, kelompok maupun LSM. Selanjutnya, bila ada orang yang mengetahui adanya api di hutan atau lahan yang patut diduga mengakibatkan timbulnya kebakaran wajib segera melaporkan ke aparat pemerintah terdekat. Penekanan kuat terhadap pelarangan pembukaan lahan dengan pemabakran tertulis dalam Pasal 6 dan Pasal 15. Proses pengawasan, disamping dilakukan setiap orang yang melihat dan mengalami kebakaran, juga dikawal oleh posko Dararhutlah bernama Manggala Agni dan BPBD langsung melakukan pemadaman. tanya bagi petani. Proyek datang dalam wajah Bintara Pembinaan Desa (babinsa), puluhan ekskavator dan kontraktor land clearing tak bernama yang tiba usai padi Sonor dipanen. Ia ini juga hadir lewat bantuan sarana produksi pertanian seperti dolomit, pupuk kimia, benih hibrida, pestisida dan traktor selama dua tahun. Namun, janji itu tak sebanding dengan fakta perempuan petani yang gagal memulai masa tanam pada Agustus 2016. Sebagian petani penggarap yang nekat menyebar benih mengeluhkan padi mereka tidak bisa tumbuh. Berhektar-hektar calon sawah tergenang air berbulan-bulan lantaran land clearing berlangsung tidak transparan dan sembrono.

Potret di atas penting dibaca sebagai penanda kegagalan pembangunan bertajuk perlindungan lahan pangan dan restorasi gambut. Setidaknya ada dua gap di Desa Talang. Pertama, Proyek Cetak Sawah diusulkan di atas penegasian terhadap ketimpangan sosial di kampung. Kedua, Proyek Cetak Sawah diduga mampu menjadi cara baru penyingkiran petani penggarap di lahan gambut. Pertanyaannya, siapa yang paling terpinggirkan dari proses Proyek Cetak Sawah ini?

Guna menjawab pertanyaan tersebut, naskah ini membangun argumentasi dari elaborasi data lapangan dan kajian meja. Data lapangan dicatat sejak Februari sampai Desember 2016 sembari mengamati dan mengikuti perubahan penting di kampung selama Proyek Cetak Sawah berlangsung. Data ini dikombinasikan dengan kajian meja yang mendudukkan Proyek Cetak Sawah sebagai konvergensi isu tentang ketahanan pangan dan restorasi gambut -dua agenda yang tidak nyambung, namun memiliki titik temu untuk menyediakan lahan skala luas. 


\section{B. Konvergensi Isu Proyek Cetak Sawah}

Senin, 18 September 2016, sebagian warga Talang berkumpul di ujung kanal swadaya usai menyadap karet di perkebunan. Satu hari sebelumnya, mereka mendengar pengumuman dari pengeras suara masjid dan pembawa berita keliling tentang rencana Gapoktan Bersatu Maju dan Direktorat Zeni TNI AD menyelenggarakan penanaman perdana di lokasi Proyek Cetak Sawah. Lima belas orang berseragam hijau loreng berdiri menyebar di sekitar rerimbunan pohon karet -mempertontonkan pengaruh tentara dalam proses penanaman perdana ini. Sementara di dalam tenda, tamu undangan duduk menanti giliran pidato. Mereka adalah komandan Komando Militer 0402, perwakilan dari Dinas Pertanian Kabupaten Ogan Komering Ilir, penyuluh pertanian, ketua Gapoktan Bersatu Maju, kepala desa, sekertaris desa, dan para gadis pembawa benih padi.

Satu per satu undangan menyampaikan sambutan, demikian pula Letnan Kolonel Kavaleri Dwi Irbaya Sandra, Komandan Komando Militer 0402. Dia berulangkali mengatakan bahwa Proyek Cetak Sawah bisa menjadi jawaban bagi bencana kebakaran yang dipicu pembukaan ladang Sonor. Pada kesempatan tersebut, ia juga memberi janji bahwa sistem sawah mampu meningkatkan panen padi menjadi dua kali dalam satu tahun. Petani melalui Gapoktan Bersatu Maju juga akan dibantu mesin traktor, bibit unggul, dan pupuk kimia gratis selama dua tahun. Sesi tanya jawab dibuka, namun terkesan basabasi karena komandan menunjuk sendiri dua orang penanya yang sudah disiapkan tentara sebelum acara dimulai. Mereka adalah anggota Gapoktan Bersatu Maju yang bertanya tentang traktor, dan perempuan pembawa benih yang bertanya tentang kemungkinan pemuda lajang untuk mendapatkan lahan cetak sawah. Selanjutnya, tidak ada hal lain yang ditanyakan selain tepuk tangan. Acara pun ditutup setelah para undangan, secara seremonial, menanam padi di petak sawah dengan disertai papan nama pejabat.

Kentalnya kehadiran militer selama proses penanaman perdana ini tidak lepas dari nota kesepemahaman Andi Amran Sulaiman, Menteri Pertanian, dengan Gatot Nurmantyo, Kepala Staf Angkatan Darat, pada o8 Januari 2015.7 Dilatarbelakangi kesepakatan tersebut, TNI AD mengerahkan 50.000 tentara babinsa untuk ikut menanam padi, mengamankan pendistribusian pupuk, sampai mendukung teknologi pertanian. ${ }^{8}$ Peran tentara babinsa ini sangat strategis menyangkut hulu sampai hilir Proyek Cetak Sawah, tak terkecuali sebagai pembina pertanian bagi kelompok tani. ${ }^{9}$ Maka, tak heran bila mulai dari proses land clearing sampai seremoni penanaman perdana sawah, Proyek Cetak Sawah selalu menyertakan tentara babinsa dan komandan komando militer territorial. Hingga hari ini, kerjasama

7 Lihat Pedoman Teknis Perluasan Sawah Pola Swakelola Tahun 2016 yang menyebutkan ada tiga dari sembilan belas landasan hukum yang berkaitan dengan keterlibatan tentara dalam Proyek Cetak Sawah. Pertama, Nota Kesepakatan Menteri Pertanian Republik Indonesia dengan Kepala Staf Angkatan Darat Nomor 01/MOU/RC.120/M/I/2015 dan Nomor 1/I/2015 tanggal 8 Januari 2015. Kedua, Surat Direktur Jenderal Prasarana dan Sarana Pertanian kepada Kepala Staf TNI Angkatan Darat Nomor 1133/SR.040/B2/12/2015 tanggal 31 Desember 2015 tentang institusi pelaksana kegiatan perluasan sawah tahun anggaran 2016. Ketiga, Surat Kepala Staf Angkatan Darat Nomor B/249/I/2016 tanggal 25 Januari 2016 tentang penetapan institusi TNI Angkatan Darat sebagai pelaksana program kegiatan perluasan sawah tahun anggaran 2016.

8 Lihat http://tni.mil.id/view-112024-peranbabinsa-dalam-swasembada-pangan.html diakses pada 1 November 2017

9 Lihat https://tirto.id/modus-tni-membantupetani-ctiU diakses pada 30 Agustus 2017 
tersebut terus berlangsung meski dugaan maladnimistrasi anggaran 3,5 trilyun per 130 ribu Hektare di tahun 2016 cukup besar serta kesangsian administratif karena aktivitas TNI AD dalam Proyek Cetak Sawah tidak disertai perintah langsung presiden. ${ }^{10}$

Janji manis selama seremoni penanaman perdana Proyek Cetak Sawah, nyatanya, hanya isapan jempol belaka. Tak berselang lama, saat hujan deras terjadi setiap hari, lokasi cetak sawah tergenang air selama berbulan-bulan sehingga mengancam daur produksi warga dalam berladang Sonor. Situasi kampung ricuh, saat petani penggarap yang bisa mulai membersihkan ladang di Bulan September menjadi menganggur. Tidak ada semak-semak yang bisa dibersihkan lantaran bentang lahan seluas 562 Hektare tergenang air. Bahkan, usai seremoni penanaman perdana, kampung juga dibuat riuh oleh simpang siur pembagian lahan cetak sawah yang dijanjikan dua Hektare per kepala keluarga. Jumlah pembagian lahan ini tentu akan berkurang bila tanah yang semula dijanjikan 1010 Hektare menyusut menjadi 865 Hektare, meski pelaksanaannya hanya 562 Hektare. Situasi kian memanas lantaran janjijanji manis semasa penanaman perdana tidak bersambut dengan realitas proyek yang ada.

Dari cerita di Desa Talang, kita sebenarnya bisa berefleksi tentang bagaimana duduk perkara dari Proyek Cetak Sawah ini? Persoalan apa yang ingin diatasi Proyek Cetak Sawah dan apa saja kesenjangannya di lapangan? Bagaimana nalar pengambil kebijakan terhadap proyek ketahanan pangan di lahan gambut justru akan mengulang kesalahan yang sama pada masa Orde Baru melalui proyek pembukaan lahan gambut sejuta Hektare? Pertanyaan-pertanyaan ini barangkali bisa sangat menggelitik, mengingat kesenjangan

1o Koran Tempo bertajuk "Pelibatan TNI tanpa Keputusan Presiden" diakses pada Selasa 13 Juni 2017 antara hal yang dicita-citakan dengan realitas proyek sangatlah jauh. Alih-alih meningkatkan ketahanan pangan, petani penggarap justru tidak bisa melanjutkan produksinya karena ekosistem mereka rusak sementara praktik perladangan Sonor dikambinghitamkan.

Membaca Proyek Cetak Sawah di Desa Talang tidak bisa dilepaskan dari narasi kebijakan yang bekerja di tingkat nasional dan global. Berdasarkan Proyek Cetak Sawah di Desa Talang, pengalaman mereka sangat terkait dengan dua narasi besar tentang "ketahanan pangan" dan "restorasi gambut". Kesan ini terbaca kuat karena Cetak Sawah menjanjikan sistem pertanian padi yang tidak membakar. "Pada akhir 2015 warga desa diberikan lahan untuk mengubah pola Sonor, kita mencoba teknologi cetak sawah demi mengurangi kegiatan Sonor (membakar lahan) namun hasilnya belum maksimal," ujar Ketua Gapoktan Bersatu Maju Desa Talang, pada Sabtu (6/05/2017)." Baik ketahanan pangan maupun restorasi gambut, di dalam praktiknya, memiliki kemiripan untuk memobilisasi dan memastikan ketersediaan lahan pangan berskala luas.

Pertemuan dua narasi inilah yang kemudian saya sebut sebagai konvergensi isu. Proyek Cetak Sawah diberi cerita tentang perluasan lahan untuk tanaman pangan di waktu bersamaan juga dibumbui cerita lain tentang pemulihan lahan gambut yang telah terdegradasi. Lantas, bagaimana dua narasi kebijakan ini bertemu dalam rangka menyediakan lahan skala luas di atas kawasan yang selama ini dianggap tidak produktif dan tidak berkepemilikan seperti lahan gambut? Saya mencoba membayangkan wajah

11 http://www.detiksumsel.com/cetak-sawah-dilahan-gambut-belum-maksimal- dan http:// www.nuansakita.com/peristiwa/cetak-sawahwujud-restorasi-lahan-gambut-yang-belumberhasil/ diakses pada 1 November 2017 
konvergensi itu dari diagram berikut, lantas mengurainya satu per satu.

Gambar 2. Diagram Konvergensi Isu Proyek Cetak Sawa

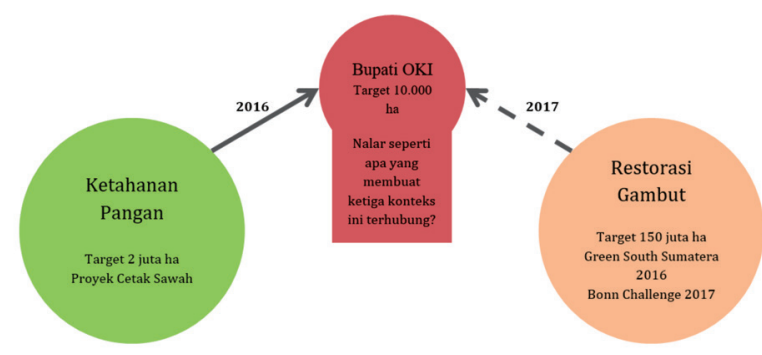

Pertama, mari kita membaca duduk perkara Proyek Cetak Sawah dari narasi tentang ketahanan pangan (lingkaran berwarna hijau). Cerita tentang cetak sawah sebagai solusi ketahanan pangan sudah berlangsung sejak 2010 saat Badan Perencanaan Pembangunan Nasional menyatakan perluasan sawah sebagai targetRencanaPembangunanJangkaMenengah Nasional (RPJMN) 2010-2014. Agenda ini, lantas, dimulai dengan penandatanganan kontrak kinerja antara Menteri Pertanian dengan Presiden untuk membuka lahan seluas dua juta Hektare sebagaimana tertulis dalam Rencana Strategis (Renstra) Kementerian Pertanian 2010-2014. ${ }^{12}$ Rancangan tersebut menyebutkan, dari dua juta Hektare lahan yang akan dibuka, 250.ooo Hektare di antaranya untuk Proyek Cetak Sawah, 400.ooo Hektare untuk pembukaan lahan kering, 400.000 Hektare untuk area holtikultura, 585.430 Hektare untuk perluasan areal perkebunan dan 364.570 Hektare pengembangan areal hijau makan ternak. Meski target Proyek Cetak Sawah lebih sedikit dibanding peruntukkan perkebunan, pembukaan lahan dengan jumlah 250.00o Hektare hanya bisa dimungkinkan

12 Target swasembada pangan untuk panen padi 75,70 juta ton dan panen jagung produksi 29 juta ton pada 2014. Target ini akan dipenuhi dengan dukungan infrastruktur pertanian berupa perluasan lahan baru sebesar 2 juta Hektare selama lima tahun, dan penyediaan pupuk sesuai kebutuhan selama lima tahun. di lahan yang dianggap terlantar oleh negara. Sebagaimana disebut Renstra Kementerian Pertanian 2010-2014, "Sebagian lahan potensi (Proyek Cetak Sawah) tersebut merupakan lahan sub optimal seperti lahan kering, rawa, lebak, pasang surut, dan gambut yang produktivitasnya relatif rendah,... tingginya kemasaman/salinitas, jenis tanah yang kurang subur."

Cerita tentang perluasan lahan pertanian sawah kembali dimunculkan pada RPJM Nasional pada 2015-2019 dengan target mencapai 1 juta Hektare di luar Pulau Jawa. Target satu juta Hektare sawah baru ini juga muncul di dalam Nawacita Jokowi untuk mencapai ketahanan pangan. "Pada 2015, program cetak sawah tahun 2015 dianggap sukses karena mampu mencapai 20.166 Hektare hanya dalam kurun waktu 120 hari kerja," ungkap Kepala Bidang Penerangan Umum (Kabidpenum) TNI Kol Czi Berlin. Berdasarkan Rencana Kerja Pemerintah (RKP) Kementerian Pertanian 2016, target perluasan Proyek Cetak Sawah dipatok mencapai 200.00o Hektare lahan baru dengan dana APBN 2,8 trilyun." "Tahun ini akan ada penambahan sawah yang cukup besar. Kita cetak 200.000 Hektare untuk seluruh Indonesia," ujar Amran di Kementrian Pertanian Senin (4/1/2016).14 Seluruh proyek diarahkan ke daerah-daerah yang dianggap lahan terlantar dan marjinal untuk mendukung peningkatan produksi padi salah satunya di kawasan gambut. Pembukaan lahan untuk sawah ini dianggap mampu mengimbangi laju konversi lahan sawah yang mencapai 100.00o Hektare per tahun sehingga

13 http://sp.beritasatu.com/home/program-tniad-cetak-sawah-sembilan-provinsi/112888 diakses 27 Oktober 2016

14 http://bisniskeuangan.kompas.com/ read/2016/o1/04/132215426/Mentan.2016. Pemerintah.Cetak.Sawah.Baru.Lebih.Banyak diakses pada 12 Juni 2017 
perlu dipatok target tinggi untuk perluasan sawah baru (Renstra Kementan 2015-2019).

Di mata Kementerian Pertanian, sebagaimana tertulis dalam Renstra Kementan 2015-2019, Proyek Cetak Sawah ditujukan bagi kompensasi atas alih fungsi lahan pertanian di Jawa yang berlangsung masif. Seperti namanya, perluasan lahan tanaman pangan ini pun tidak lepas dari bias sistem sawah ala Jawa yang berada di lahan mineral -bukan gambutdengan sistem irigasi -bukan pasang surut-. Kondisi ini, secara formal, tertuang dalam Peraturan Menteri Pertanian Nomor 48 Tahun 2006 tentang Budidaya Tanaman Pangan yang Baik dan Benar. ${ }^{15}$ Bahkan Kementerian Pertanian menyebutkan, pertanian pangan seyogyanya memiliki nilai tambah terhadap jasa lingkungan dengan ekosistem tertentu seperti gambut. Kombinasi ini, pada akhirnya, diterjemahkan secara vulgar dari praktik implementasi Proyek Cetak Sawah di Desa Talang. Sawah dianggap sebagai sistem pertanian yang layak bagi lahan gambut karena mampu memberikan jasa lingkungan positif. ${ }^{16}$

15 Peraturan ini melakukan generalisasi terhadap satu sistem pertanian tunggal yakni sawah dan menegasikan sistem produksi pangan lainnya seperti perladangan Sonor. Sebagai contoh, lahan mensyaratkan adanya status kepemilikan yang jelas disertai dengan sistem irigasi yang baik. Di dalam metode penyiapan lahan, pembakaran dianggap tidak ada. Disamping itu, pemerintah hanya mengakui varietas unggul yang terdaftar dengan sertifikat bibit yang jelas perusahaannya. Penanaman benih pun dilakukan dengan ditanam mengikuti teknik budidaya yang dianjurkan jarak tanamnya, alih-alih benih disebar seperti pada sistem perladangan.

16 (1) mengatur tata air dan mengurangi kedalaman saluran drainase, (2) intensifikasi pertanian di lahan gambut dapat mengurangi tekanan terhadap perluasan area budidaya di lahan gambut, (3) meminimalisir penggunaan lahan gambut untuk areal pertanian dan mengutamakan penggunaan lahan mineral (lihat Renstra Kementerian Pertanian 20152017). Tiga anggapan ini di satu sisi meniadakan sistem budidaya pangan di lahan gambut dan
Sementara duduk perkara kedua, tentang recana pembangunan bertajuk restorasi gambut, muncul di Provinsi Sumatera Selatan usai bencana kebakaran hutan melanda 612.833 Hektare $^{17}$ lahan gambut di Sumatera Selatan. Hampir seluruh proyek menuntut penyediaan dan penguasaan lahan skala luas, "On the province with low population densities, lack of infrastructure and rich forest, extensifications is actively sought ... in attracting land-based investors ${ }^{18}$ ". Momen kebakaran menjadi alasan Pemerintah Provinsi Sumatera Selatan untuk melangsungkan proyek ekstensifikasi bertajuk pertanian dan restorasi gambut melalui penguatan kemitraan perusahaan, konservasionis, dan masyarakat sipil. Oleh Gubernur Sumatera Selatan, Alex Nurdin, proyek ini dinamai sebagai Green Growth Plan yang menklaim mampu menekan kebakaran hutan dan lahan hingga 99,87\% pada 2016. ${ }^{19}$ Maka tak heran bila, cerita tentang Proyek Cetak Sawah di Sumatera Selatan baru ditangkap pada 2016 dan dianggap sebagai kesempatan yang saling menguntungkan bagi narasi ketahanan pangan dan restorasi lahan gambut.

Pada periode pendanaan 2016 inilah, Desa Talang mendapatkan jatah Proyek Cetak Sawah. Proyek ini, menurut Gubernur Sumatera Selatan Alex Nurdin, dianggap

dianggap sebagai permasalahan, sebagaimana sistem perladangan pada umumnya.

17 h t t p s : / / m.te m p o.co/ r e a d / news/2015/11/30/058723445/bencana-asap612-ribu-Hektaree-hutan-terbakar-disumatera-selatan diakses pada 13 juni 2017

18 http://greengrowth.sumselprov.go.id/index. $\mathrm{php} / \mathrm{en} / 14$-launching-document-greengrowth-south-sumatra.html diakses pada 12 Juni 2017

19 http://sumsel.antaranews.com/berita/31539o/ ogan-komering-ilir-sediakan-10ooo-Hektareerestorasi-gambut?utm_source $=$ fly\&utm medium $=$ related $\& u t m_{-}$campaign $=$news diakses pada 5 Juni 2017 
sebagai proyek yang berhasil lantaran mampu membuat Sumatera Selatan surplus beras 2,2 juta ton tahun 2016. ${ }^{20}$ Keberhasilan ini, menurut Kepala Dinas Pertanian Tanaman Pangan dan Holtikultura Provinsi Sumatera Selatan, Erwin Noor, bisa lebih ditingkatkan selagi ada bantuan dana bagi lahan rawa yang jumlahnya mencapai 226.00o Hektare. ${ }^{21}$ “Terutama jika ada hibah dari negara donor dalam kaitannya dengan pencetakan sawah di lahan gambut tipis," tambahnya yang lantas ditangkap sebagai peluang bagi skema Green Growth Plan.

Baik narasi tentang ketahanan pangan maupun restorasi gambut, di dalam konteks Sumatera Selatan khususnya Ogan Komering Ilir, bisa saling bertemu. Di satu sisi, Menteri Pertanian membuat target tinggi 200.000 Hektare untuk Proyek Cetak Sawah. “Tahun ini akan ada penambahan sawah yang cukup besar. Kita cetak 200.ooo Hektare untuk seluruh Indonesia," ujar Amran di Kementrian Pertanian Senin (4/1/2016). Di sisi lain, Pemerintah Ogan Komering Ilir juga menyediakan lahan seluas 10.00o Hektare untuk mendukung program Proyek Cetak Sawah yang juga dibungkus sebagai restorasi gambut.

"Lahan ini (10.0oo Hektare) memang diproyeksikan pemerintah kabupaten untuk hutan produksi, tapi jika bisa dijadikan sawah dengan teknologi yang dimiliki apa salahnya. Pemerintah Kabupaten OKI siap memfasilitasinya karena lahan ini merupakan lahan tidur," kata Bupati Ogan Komering Ilir. ${ }^{22}$

20 http://sumsel.antaranews.com/berita/311499/ sumsel-optimistis-surplus-beras-27-juta-ton Diakses pada 5 Juni 2017

21 http://sumsel.antaranews.com/berita/311499/ sumsel-optimistis-surplus-beras-27-juta-ton Diakses pada 5 Juni 2017

22 http://sumsel.antaranews.com/berita/31146o/ oki-tawarkan-lahan-10ooo-Hektaree-jadisawah diakses pada 5 Juni 2017
Kesempatan ini diutarakan Bupati Ogan Komering Ilir saat mendapat kunjungan Bonn Challenge 2017, sebuah perhelatan internasional 27 menteri lingkungan hidup Asia Pasifik untuk berbicara tentang restorasi gambut di Desa Sepucuk Kayu Agung. Di dalam cerita yang sama, Badan Restorasi Gambut juga membuat target 848.325 Hektare lahan di Provinsi Sumatera Selatan yang mampu direstorasi pada 2016-2020. ${ }^{23}$

Gambar 3. Bagan Keterkaitan Narasi Ketahanan Pangan dan Restorasi Gambut

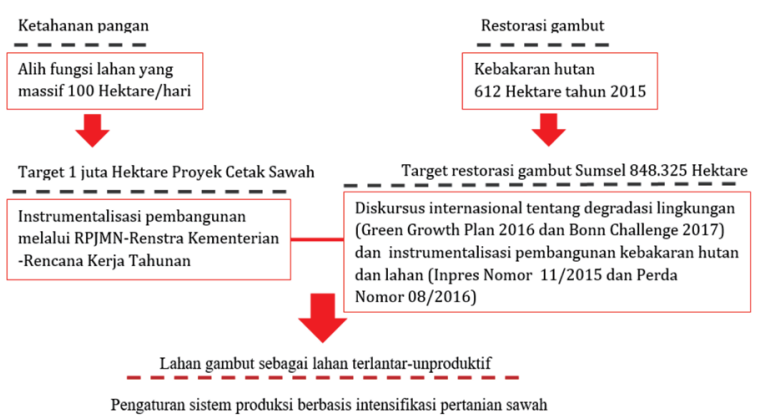

Dari paparan di atas, narasi tentang ketahanan pangan dan restorasi gambut memiliki dua kaitan yang mereproduksi asumsi kolonial tentang kawasan gambut. Di satu sisi, ekosistem gambut diasumsikan sebagai "lahan terlantar atau lahan tidak produktif dan lahan tidur". Di sisi lain, sistem produksi di kawasan gambut selalu dianggap terbelakang sehingga membutuhkan intervensi pembangunan. Dua konsep ini menjadi titik temu dari dua narasi yang seolah-olah tidak nyambung namun terhubung kuat.

Titik temu pertama ialah kedua narasi memiliki anggapan tentang lahan gambut sebagai lahan tidak produktif, lahan terlantar dan lahan tidur. Istilah ini selalu hadir tanpa definisi yang jelas, namun selalu kerap diulang dalam skema pembangunan maupun perbincangan internasional. Baik RPJMN, Renstra Kementerian

23 https://brg.go.id/restorasi-gambut-sumseldiperkuat-dalam-nota-kesepahaman-brg-ridan-pemprov-sumatra-selatan/ diakses pada 11 November 2017 
Pertanian sampai Buku Panduan Proyek Cetak Sawah menyebut ekosistem gambut sebagai lahan terlantar yang perlu diatur negara karena rentan mengalami bencana kebakaran. Hanya saja, sejak pemerintahan kolonial, pengaturan negara terhadap kawasan gambut bukanlah persoalan gampang. Pengaturan negara atas kawasan gambut selalu terhambat persoalan infrastruktur untuk pengawasan sehingga hanya mengandalkan klaim kartografi semata. Sebagai contoh, pada periode 193oan, banyak konsesi Jerman dan Amerika untuk komoditas karet jelutung (dyera lowii) di kawasan gambut Kalimantan terlantar karena ketidakmampuan mengakses interior hutan (Potter 1988). Meski menghasilkan kesia-siaan, pengaturan negara terhadap kawasan gambut tetap berlangsung dengan membuat pemisah antara lahan budidaya yang bias tanah mineral dan lahan terlantar yang bias tanah gambut. Pengaturan ini disebut sebagai domain tanah negara, walaupun gagal, tetap mampu menyajikan satu pondasi legal dan instrumentalisasi tentang ekosistem gambut sebagai lahan terlantar dan tidak produktif (Peluso dan Vandergeest 2001 dan 2006).

Pondasi legal ini setidaknya didasari pada kehendak negara untuk melakukan legibilitas dan simplifikasi terhadap kawasan yang sulit diatur (seperti kawasan gambut) dengan cara mengukur dan menkalkulasi untuk keperluan pembangunan dan investasi (Scott 1999). Sebenarnya, "mereka tidak perlu harus melihat ke lokasi secara langsung, sebab yang dibutuhkan hanya akurasi di atas meja dan peta," (Scott 1999, 10). Didasari pada logika inilah, seluruh proyek pembangunan -tanpa terkecuali dalam narasi ketahanan pangan dan restorasi gambut- bekerja. Proses legibilitas dan simplifikasi ini tidak hanya difasilitasi oleh ilmu kartografi semata tetapi juga ilmu botani dengan melakukan kategorisasi terhadap tanaman budidaya dan non budidaya. Kategorisasi ini menegasikan tanaman di dalam siklus produksi perladangan dan mengakomodir seluruh tanaman keras untuk komoditaseksporyang sudah berlangsung sejak abad 15 (seperti lada, cengkeh, pala, dan pinang -dibahas pada bab selanjutnya). Pembedaan ini begitu kentara dalam cerita tentang karet jelutung (dyera lowii) yang dianggap sebagai tanaman endemik dan karet budidaya (hevea brasiliensis) yang diperkenalkan pada abad 20 (Dove 2011 dan Potter 1988). Kawasan yang dikategorisasi sebagai ruang bagi tanaman endemik akan mengalami proses teritorialisasi melalui serangkaian ragam regulasi dan kontrol atas lahan untuk menjadi kawasan hutan (Peluso dan Vandergeest 1996 dan 2001).

Pengaturan terhadap domain tanah negara ini tidak hanya menyediakan lahan skala besar bagi negara melainkan juga tenaga kerja bebas. Negara mengosongkan ruang, memisahkannya dengan keseharian petani, agar sumber daya di atasnya bisa diperuntukkan bagi investasi. Proses pemisahan ini dilakukan melalui serangkaian instrumentalisasi untuk menyebut corak produksi tertentu di atas ruang yang dikosongkan itu sebagai terbelakang. Negara menjadi wajah teknopolitik karena disetir diskursus global untuk menginternalisasi pembangunan dan modernisasi teknologi produksi pertanian, seperti pada Revolusi Hijau pada 1970an (Tsing 2005, 21). Konteks ini menjadi titik temu kedua di mana negara sebagai teknopolitik melakukan marjinalisasi terhadap sistem produksi perladangan. Sistem produksi perladangan ini dibenturkan secara vulgar dengan sistem pertanian sawah yang dianggap ramah lingkungan dan lebih modern dalam menggunakan teknologi intensifikasi pertanian. ${ }^{24}$

24 Rasionalisasi petani dalam melakukan penebangan dan pembakaran untuk membersihkan lahan pertanian, seperti disebut dalam penelitian Ketterings dkk (1999) pasca kebakaran lahan gambut 1997 di Sumatera: 
Marjinalisasi negara terhadap sistem produksi perladangan ini semakin meningkat seiring kebakaran lahan yang kian intensif. Setidaknya ada empat konteks marjinalisasi ini, sebagaimana disebut (Fox dkk 2009) tentang ekonomi politik perladangan. Pertama, perladangan merupakan sistem agroforestri yang menggabungkan tata guna lahan untuk budidaya tanaman dan reforestasi. Hanya saja, seiring teritorialisasi negara, sistem ini justru terjebak pada yuridiksi hutan dan lahan budidaya di mana otoritas politik dan birokrasinya jauh berbeda. Kedua, melalui serangkaian legitimasi, negara seolah memiliki otoritas untuk memindahkan dan mendisposesi petani penggarap dari ladangnya. Lantaran posisi negara yang enggan berpikir komprehensif, maka marjinalisasi ketiga, negara menutup mata pada ancaman ekspansi kapitalis untuk mendorong produksi komoditas monokultur. Keempat, komodifikasi lahan dan produknya mendorong adanya ekspansi infrastruktur dan pasar tenaga kerja bagi kerja non pertanian, sehingga semakin menenggelamkan sistem produksi perladangan.

Pertanyaannya kemudian, pada konteks seperti apakah Proyek Cetak Sawah hadir di kampung? Pertanyaan inilah yang menjadi dasar bahwa Proyek Cetak Sawah sebagai proyek pembangunan perlu diletakkan dalam sejarah dinamika sosial dan ekologi di Desa Talang. Penjelasan sejarah ini bisa

Petani menyebutkan ada lima keuntungan dari "menebang dan membakar" sebagai cara untuk membersihkan lahan: (1) sisa-sisa kayu bekas penebangan bisa menjadi penyubur tanah, (2) Petani jadi bisa mengurangi biaya untuk menyiangi rumput selama proses pertanian karena telah berkurang akibat pembakaran, (3) membakar menciptakan ruang untuk menanam dan berjalan, (4) membakar mengurangi hama tanaman yang mengancam produksi tanaman, (5) membakar meningkatkan struktur tanah agar bibit yang disebar bisa lebih mudah tumbuh. mendudukkan perkara bahwa dua asumsi tentang kawasan gambut dalam programprogram pembangunan merupakan reproduksi kolonial untuk menyediakan lahan berskala luas.

\section{Dinamika Sosial Ekologis Desa Talang}

Dari diskusi sebelumnya, Proyek Cetak Sawah sebagai proyek pembangunan tidak bebas nilai. Ia hadir dalam dua asumsi yang sejatinya bias kolonial. Kedua asumsi ini meniadakan latar belakang sejarah perubahan hubungan manusia dengan ekologinya. Kecenderungan anti-sejarah membuat seluruh proyek, seperti disebut Ferguson (1994) dan Li (2005) tidak pernah mengatasi ketimpangan sosial yang ada. Maka di sini, saya ingin meletakkan duduk perkara Proyek Cetak Sawah dalam pertanyaan, mengapa warga mengusulkan Proyek Cetak Sawah sementara mereka memiliki sistem perladangan Sonor yang lebih mandiri? Guna menjawab kegelisahan ini, penting untuk melacak hubungan antar warga dan warga dengan ekologinya. Bagian pertama menjelaskan tentang babak sejarah sosial dan ekologi di Desa Talang yang tidak lepas dari perladangan Sonor dan ledakan komoditas karet hevea brasiliensis. Bagian kedua merupakan elaborasi dari bias Proyek Cetak Sawah.

\section{Babak Sejarah Sosial dan Ekologi}

Menurut kisahnya, Desa Talang secara resmi lahir pada 1920 yang ditandai penanaman komoditas karet hevea brasiliensis. Cara warga menandai kelahiran kampung dengan tanaman komoditas bukan tanpa alasan. Kehadiran karet di antara petani penggarap mensyaratkan konsentrasi penduduk di kawasan tertentu untuk memudahkan pengerahan tenaga kerja keluarga selama proses produksi karet. Rumah tangga tani berkumpul di sekitar 
lahan bertanah mineral yang adaptif terhadap pohon karet. Di samping itu, pembentukan administrasi desa juga memudahkan pungutan pajak dari proses jual beli komoditas karet.

Kehadiran karet hevea brasiliensis, disebut Dove (1994), mampu menjamin keamanan tenurial bagi petani penggarap. Bahkan, karena karet pula, pola perladangan berpindah dan mobilitas rumah tangga tani penggarap menjadi mandeg (Dove 1994 dan 2011). Padahal, seperti disebutkan Reid (1984 dan 1995), Sumatera pada masa sebelum kolonialisasi merupakan open frontier -tempat di mana ruang jelajah baru untuk produksi pangan masih berlimpah-. Demikian pula dengan Desa Talang, bagi siapa pun yang membuka dan menggarap lahan, maka ia memiliki hak atas lahan tersebut. Lambat laun, ruang jelajah baru ini kian susut seiring dengan perubahan komoditas di tiap sejarah sosial dan ekologi Desa Talang.

Jauh sebelum komoditas karet hevea brasiliensis, penduduk Sumatera Selatan memenuhi hidup dari corak produksi prakolonial yakni perladangan rotasi (Reid 1984). Pada musim kemarau, mereka membersihkan pohon dan membakar lahan yang berisi semak-semak sebagai unsur hara utama bagi tanaman. Mayoritas ekosistem di Sumatera Selatan merupakan bentang lahan yang tidak terkena aktivitas volcano namun ditumbuhi hutan hujan tropis yang lebat sehingga terkenal kurang subur, kemudian disebut ekosistem gambut.

"Sebagian besar tanah merupakan endapan dedaunan dan pepohonan yang mudah terurai dalam iklim tropis,... tanpa pembersihan dan pembakaran, tanaman pangan tidak bisa matang secara memuaskan,"(Fisher 1966).

Menimbang karakter gambut ini, tidak heran bila membakar merupakan corak produksi tua yang bertahan dari generasi ke generasi. "Bahkan, masyarakat melakukan ritual terlebih dulu sebelum membakar," ujar sesepuh Desa Talang. Sistem ini memiliki daur produksi yang cepat, satu kali musim tanam sampai panen setiap tahun. Setelah padi dipanen, petani penggarap akan pindah ke lain tempat dengan cara menanami lahan yang sebelumnya dengan tanaman keras seperti pohon buah-buahan (Fox dkk 2009). Melalui cara inilah, petani menandai hak guna yang disesuaikan dengan curahan kerja masingmasing orang. Seiring berjalannya waktu, lahan untuk berpindah kian menyusut karena perubahan sistem produksi petani penggarap dari perladangan menjadi perkebunan komoditas ekspor dan teritorialisasi negara.

Pertama, penyusutan akses terhadap lahan garapan dilatarbelakangi perubahan sistem produksi dari pertanian subsisten menjadi perkebunan komoditas ekspor. Pengenalan terhadap komoditas ekspor hadir bersamaan dengan terbukanya jalur perdagangan lada yang melewati pelabuhan-pelabuhan tua Sungai Musi di Palembang. Meningkatkan pasar komoditas lada membawa dampak signifikan terhadap ekosistem gambut di Sumatera Selatan sejak abad 17 sampai abad 19. Pada abad 17 dan 18, Pulau Sumatera mampu menghasilkan setidaknya 5000-7000 ton lada per tahun. Pendapatan dari kebun lada ini melonjak tajam pada abad 18 hingga 20.000 ton/tahun (Reid 1984). Jumlah panen yang meningkat ini sejalan dengan luasan hutan yang beralihfungsi menjadi kebun lada, hampir 1,6\% dari total luas Pulau Sumatera. Kebun lada menyisakan bentang lahan yang dipenuhi alang-lang dan padang rumput permanen, sulit untuk melakukan reforestasi dengan tanaman keras. Meski pohon lada bukan tanaman keras, namun daur panen lada yang baru dimulai tahun ke tiga (Reid 1984) membuat putaran lahan untuk perladangan rotasi menjadi 
mandeg. Perkebunan lada menyisakan catatan sejarah penting di Sumatera Selatan meski hasil panen untuk lada merosot tajam dibanding abad $19 .{ }^{25}$

Memasuki abad 20, tren ledakan komoditas ekspor berganti menjadi budidaya karet hevea brasiliensis. Komoditas karet hevea brasiliensis ini -jauh sebelum penetrasi kapital perkebunan skala besar- dikerjakan petani penggarap yang sebelumnya berladang rotasi di kampung. Di awal abad 20, alih fungsi kawasan hutan untuk perkebunan karet serta komoditas teh dan tembakau dinilai lebih luas (Reid 1995). Kesaksian senada juga dikisahkan sesepuh Desa Talang bahwa pada 1916 semasa Pemerintah Hindia Belanda setiap petani wajib memiliki kupon merah sebagai tiket menjual hasil karet mereka. Pengenalan komoditas karet memang diperuntukkan bagi petani penggarap bukan perusahaan skala besar. Bila di tahun 1912 sudah ada jual beli karet, maka bisa dimungkinkan pohon karet sudah ditanam sejak 1905an.

Ditanaminya pohon-pohon komoditas ini menandai perubahan penguasaan lahan. Bagi petani penggarap yang menanami lahan garapan dengan pohon karet, berikutnya, dia akan menjadi pemilik lahan. Harga yang baik dan proses penyadapan yang efisien menjadi alasan rasional bagi petani penggarap menanam karet. Pada masa kolonial, sebelum krisis 1930, harga karet cukup stabil. Saat zaman Jepang, produksi karet sempat turun karena ada kewajiban membayar pajak tanaman bukan pangan dan kerja paksa. Konon, tentara Jepang banyak yang menyebar sampai ke kebun-kebun karet untuk mencari

25 Berdasarkan, http://bppm.kaboki.go.id/index. php/investasi/peluang-dan-potensi diakses pada 14 Juni 2017, hanya 56 Hektare lahan saja yang ditanami komoditas lada di Ogan Komering Ilir dengan hasil panen 15 ton per tahun. tenaga produktif bagi kerja paksa.

Setelah kemerdekaan, para petani Talang menandai masa Orde Baru dengan hadirnya konsesi ektraksi kayu di kawasan hutan gambut. Pada 1979 sampai 1991, warga mengenal hak pengusahaan hutan (HPH) PT Ramin Jaya yang mencakup Desa Talang dan lima desa tetangganya. Perusahaan ini mencari pohon ramin, meranti, dan gelam yang pada waktu itu sedang baik harganya. Ekstraksi terus menerus menyebabkan hutan gambut di sekitar Talang menjadi terdegradasi, hingga puncaknya saat El Nino 1997 kebakaran besar pun tak terhindarkan. Kebakaran ini menyebabkan kerugian bagi petani yang kebun karetnya ikut terbakar. Meski demikian, periode akhir 1990an juga menjadi momen berharga karena uang begitu mudah diperoleh dari aktivitas penebangan kayu. Sebagian besar lelaki di Desa Talang merantau sebagai buruh penebang kayu ke kawasan gambut sekitar Sumatera Selatan, Riau sampai ke Kalimantan. Namun, periode ini tak berlangsung lama, karena pendisiplinan terhadap penebangan kayu berangsur-angsur ketat. Bahkan pada 1999, lokasi konsesi PT Ramin Jaya diperuntukkan bagi Suaka Margasatwa Padang Air Sugihan oleh pemerintah pusat. Tanpa ada proses sosialisasi dengan warga, kawasan hutan yang menjadi lokasi logging dan perluasan perladangan Sonor dipatok sebagai rencana kawasan Suaka Margasatwa Padang Air Sugihan. Bahkan dari cerita warga, patokpatok itu ditancapkan hanya tiga kilometer dan mencakuparea kelola warga untuk perladangan Sonor. Patok-patok penanda batas ini ditanam asal-asalan sesuai kemampuan pemasang patok menembus lumpur gambut. Di dalam prosesnya, warga desa sama sekali tidak diberi informasi tentang adanya pemasangan batas Suaka Margasatwa Padang Air Sugihan. Keresahan ini berujung pada konflik dengan pihak kepolisian dan kehutanan tahun 2001 
saat kawasan suakamargasatwa ini ditetapkan oleh Departemen Kehutanan RI.

Belum selesai dengan persoalan dengan suaka margasatwa, pada 2005 terbit konsesi perkebunan kelapa sawit PT Bumi Andalas Permai yang mencakup lahan kelola warga Talang seluas 700 Hektare. Perlawanan ini berujung unjuk rasa di Kabupaten Banyuasin menuntut hak kelola mereka. Di tahun yang sama, Bupati Ogan Komering Ilir kembali menerbitkan ijin kepada PT Persada Sawit Mas dengan luas 45.ooo Hektare mencakup tiga kecamatan. Seperti halnya pada PT Bumi Andalas Permai, masyarakat Talang juga melakukan unjuk rasa kepada pemerintah Kabupatepen Ogan Komering Ilir. Lantaran protes tidak ditanggapi, aksi tersebut berujung pada pembakaran camp pekerja yang berimbas pada penetapan 28 orang lelaki sebagai daftar pencarian orang. Di dalam protes ini, ada dua orang meninggal -satu dari pihak perusahaan dan satu warga yang dihakimi warga karena mencoba mengintimidasi aksi mempertahankan lahan. Perjuangan ini berlangsung panjang sampai tiga tahun, hingga pada 2009, Pemerintah Kabupaten Ogan Komering Ilir bersepakat mengembalikan lahan warga seluas 5.50o Hektare.

Gambar 4. Peta Desa Perigi

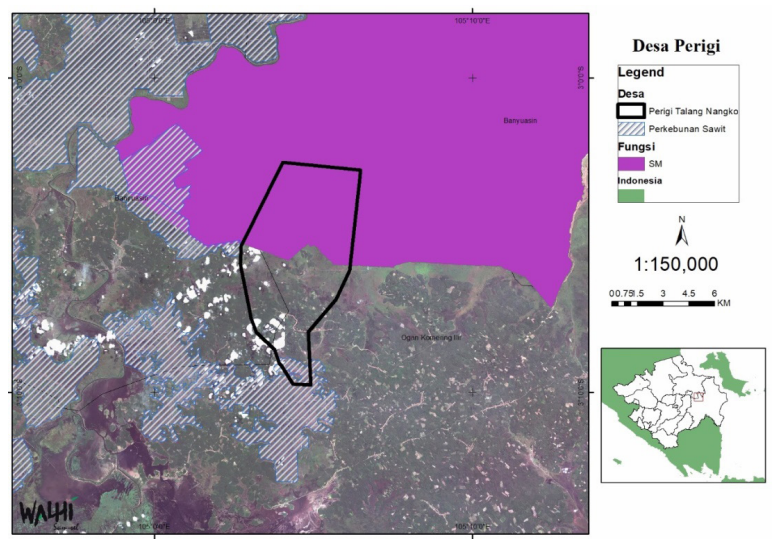

Sumber: WALHI Sumatera Selatan.

\section{Keterangan}

Garis hitam merupakan wilayah kelola petani penggarap untuk perladangan sonor. Dari peta tersebut kita bisa melihat kawasan kelola Desa Talang telah diklaim sepihak oleh Suaka Margasatwa Padang Air Sugihan, yang dulunya konsesi HPH PT Ramin Jaya. Kini, kawasan ini terkepung konsesi perkebunan sawit di sisi barat, dan hutan tanaman industri di sisi timurnya.

Kemenangan terhadap perjuangan panjang merebut wilayah kelola untuk perladangan Sonor ini tidak diimbangi dengan situasi harga karet yang jatuh selama satu dekade ini. Pada 2008, harga karet turun hampir lima kali lipat dibandingkan 2005. Badan Pusat Statistik (2014) mencatat harga karet mentah pada 2005 mencapai 31.719 rupiah lantas turun sampai 5.608 rupiah. Kondisi di tahun 2008 tidak bergeser signifikan di tahun-tahun berikutnya, semisal di tahun 2009 harga meningkat 6.584 rupiah, 2010 meningkat sampai 11.928 rupiah, 2011 mencapai 12.814 rupiah 2013 sekitar 10.516 rupiah dan pada 2014 senilai $8.871 .{ }^{26}$ Ironisnya lagi, apa yang dicatat oleh Badan Pusat Statistik dalam Statistik Perkebunan Indonesia jauh dari realitas petani. Sejak 2014 sampai 2016, harga karet di Desa Talang berada di kisaran 4.0oo rupiah per kilogram. Kondisi yang tidak menguntungkan ini memaksa warga mencukupi kebutuhan hariannya dari sektor lain. Bagi perempuan memenuhi kebutuhan dari perladangan Sonor menjadi pilihan taktis karena mereka tidak perlu repot merawat padi

26 Disebutkan dalam berita bahwa harga karet setelah empat tahun mengalami penurunan drastis, sebagai ilustrasi bila di 2011 harga karet bisa mencapai 4 USD maka di kondisi setelahnya sampai 2015 hanya berkisar 1 USD saja per kilogramnya. Informasi ini diakses dari https://finance.detik.com/industri/3087770/ harga-karet-merosot-hingga-75-dalam-4tahun-terakhir pada 1 November 2017 
dengan biaya besar. "Sebab harga karet sekarang jauh di bawah harga beras," ungkap Nye Elok, salah satu petani perempuan. Disamping Nye Elok, mayoritas petani maupun buruh penyadapan karet berbondong-bondong membuka ladang Sonor pada 2015.

Pada 2014, warga Desa Talang melakukan musyawarah untuk membuat kanal swadaya sebagai sarana mengakses lahan untuk perladangan Sonor. Disamping menjadi sarana transportasi, kanal swadaya ini dibutuhkan untuk mengurangi genangan air di lahan kelola warga akibat kepungan konsesi perkebunan sawit dan hutan tanaman industri. Kanal ini menjadi bukti nyata dari hak kelola warga Desa Talang bila sewaktu-waktu terjadi perampasan lahan secara sepihak oleh konsesi-konsesi besar. Rasa was-was ini tentu wajar lantaran pasca otonomi daerah, kawasan gambut menjadi target pemerintah daerah untuk konsesi hutan tanaman industri dan perkebunan kelapa sawit. Bahkan, pada saat kanal dibangun, ada simpang siur pemberian konsesi kepada PT Kikim Rambang yang bergerak di perkebunan kelapa hibrida oleh Pemerintah Kabupaten Banyuasin.

Tahun 2015 menjadi penanda penting bagi situasi Desa Talang. Di saat harga karet belum membaik, bencana kebakaran terjadi pada musim kemarau. "Berdasarkan data per 6 Oktober 2015, titik panas di Kabupaten Ogan Komering Ilir (OKI) terdeteksi paling banyak, yakni mencapai 376 titk," ujar Indra Purnama dari BMKG Sumatera Selatan. ${ }^{27}$ Bahkan menurut Ketua Gapoktan Desa Talang, "Pada 1991 dan 1997 saat ada perusahaan kayu HPH, kebakaran hutan itu terbatas. Sampai saat HTI dan ijin sawit dikeluarkan, yang terbakar menjadi besar sekali." Meski sempat mengalami kebakaran hutan hebat, namun perladangan Sonor Desa

27 http://www.antaranews.com/berita/522137/ bencana-asap--titik-panas-terbanyak-di-ogankomering-ilir diakses pada 2 November 2017.
Talang masih terselamatkan sehingga bisa panen secara serampak pada Maret sampai April 2016. Hanya saja, bencana kebakaran hutan pada 2015 melahirkan Peraturan Daerah No 8 Tahun 2016 yang menegaskan pelarangan pembakaran lahan dan hutan oleh individu maupun badan hukum untuk alasan apapun tanpa seijin pejabat yang berwenang. Peraturan ini mengerahkan keterlibatan semua instansi pemerintah, termasuk perangkat desa untuk memantau praktik pembakaran lahan dan potensi terjadinya titik api. Dari peraturan daerah ini, pembakaran lahan dianggap sebagai tindakan pidana yang wajib diusut oleh kepolisian dan pengadilan dengan ancaman hukum enam bulan kurungan atau denda 50 juta.

Akibat peraturan daerah tentang kebakaran hutan, petani penggarap harus menimbang ulang aktivitas penyiapan ladang yang dilakukan dengan cara membakar. Usai merayakan panen padi Sonor pada Maret sampai April 2016, simpang siur Proyek Cetak Sawah pun terdengar. Proyek Cetak Sawah ini disebut-sebut Bupati Ogan Komering Ilir sebagai strategi mengatasi harga karet yang tidak baik sekaligus solusi untuk menanggulangi kebakaran hutan dan lahan. Pemerintah Ogan Komering Ilir memberi target 11.000 Hektare untuk pembukaan sawah baru pada 2016, di mana Desa Talang menyumbang 1.010 Hektare di antaranya.

"Kalau ada lahan yang bisa dibuat pertanian silahkan diusulkan kepada kami. Kita buka cetak sawahnya. Kita bantu buka lahan, bibit, pupuk kita kasih. Programnya sudah ada masyarakat bisa menggunakan dengan sebaik-baik," ujar Iskandar Bupati Ogan Komering Ilir (8/3/2016). ${ }^{28}$

28 http: / / palembang.tribunnews. com/2016/o3/o8/harga-karet-terpurukbupati-oki-jadikan-pertanian-sebagai-solusi diakses pada 2 November 2017 
Janji Bupati Ogan Komering Ilir pun disambut usulan rencana Proyek CetakSawaholeh Gapoktan Bersatu Maju Desa Talang. Rencananya, Gapoktan Bersatu Maju akan membuat percetakan sawah sebagai respon larangan pembakaran ladang di atas lahan 2500 Hektare, di mana 1010 Hektare di antaranya melalui proyek pemerintah. Jumlah 2500 Hektare ini tentu tidak sebanding dengan klaim wilayah kelola masyarakat Talang yang mencakup 6782 Hektare di atas kawasan yang kini menjadi Suaka Margasatwa Padang Air Sugihan. Pada awalnya, usulan Proyek Cetak Sawah ini dianggap sebagai strategi karena perladangan dengan cara membakar telah dilarang. Sementara itu, petani penggarapharusmelanjutkan pertanian padi untuk mencukupi kebutuhan pangan yang tak mampu ditutupi dari penjualan karet. Tetapi, seiring berjalannya waktu, proyek ini menyimpan bara saat musim tanam 2016 gagal dilakukan, mengapa kesenjangan Proyek Cetak Sawah begitu besar dari realitas keseharian di kampung?

\section{Bias Pembangunan Proyek Cetak Sawah}

Proyek Cetak Sawah dengan mobilisasi lahan skala besar belum mampu menjawab kebutuhan petani penggarap terhadap kecukupan pangan mereka. Proyek ini justru menyimpan empat bias, antara lain: proyek berlangsung searah, proyek tidak didasari pembacaan serius terhadap realitas sosial, proyek ini bias gender, dan menyimpan stigma terhadap sistem produksi perladangan.

Bias pertama berkaitan dengan implementasi proyek yang tidak transparan seiring kentalnya keterlibatan militer. Bias ini cukup terasa saat mengikuti pengalaman petani penggarap yang tidak mengetahui prosedur land clearing di lahan mereka. Gapoktan Bersatu Maju selaku pengusul proposal cetak sawah tidak mengetahui nama kontraktor land clearing, dan dokumen penting syarat land clearing seperti Upaya Pengelolaan Lingkungan Hidup [UKL] dan Upaya Pemantauan
Lingkungan Hidup [UPL]. Bahkan, Ketua Gapoktan mendapatkan ancaman dari babinsa bila tidak mau menandatangani berita acara land clearing. Berita acara ini menuliskan luasan land clearing 865 Hektare, jumlah ini tidak sesuai dengan usulan di awal 1o1o Hektare dan tidak sesuai realitas pelaksanaan proyek di lapangan seluas 562,7 Hektare. Luasan riil ini baru diketahui saat Gapoktan Bersatu Maju bersama Sahabat WALHI Sumatera Selatan melakukan pemetaan di lokasi land clearing. ${ }^{29}$

"Ketika bicara soal, surat berita acara penyerahan lahan. Pak ini ada berita acara, udah itu aja, saya tolak. Say abelum bsia mennandatangani soalnya kudu menunggu dulu. Ada paksaan dari mereka, tapi kami tidak mau. Program ini, ada kecurigaan pengusul awal. Usulan pertama 110 Hektare, realisasi 865 dan berita acara langsung jadi. Mereka saja mengatur, si tentara itu," ungkap Ketua Gapoktan Bersatu Maju Desa Talang.

Gambar 5. Peta Pengukuran Partisipatif Masyarakat Desa Perigi Tahap I

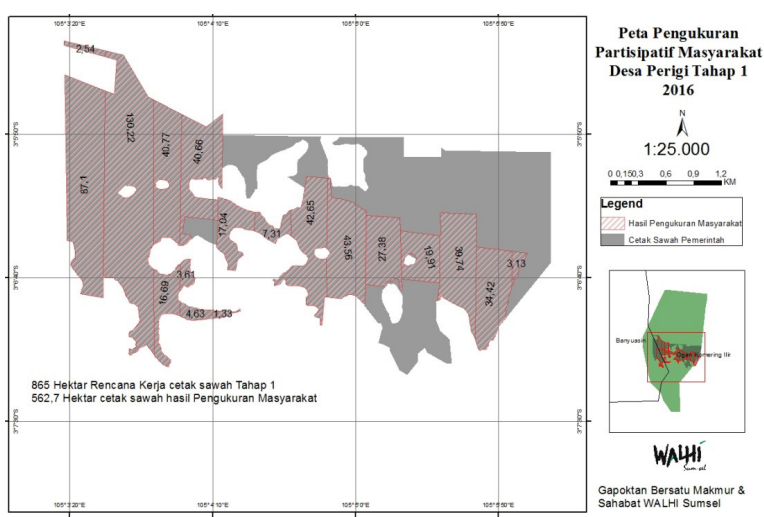

Sumber: WALHI Sumsel

29 "Untuk mencetak satu Hektare sawah diperlukan biaya sekitar Rp 10 juta. Dana ini diberikan dalam bentuk bantuan sosial (bansos) kepada petani. Penyaluran dananya langsung ke masing-masing gabungan kelompok tani (gapoktan), dan bukan ke individu. Lalu dari gapoktan dibagi-bagi lagi untuk berbagai keperluan dalam membuka areal perluasan tanah (Buku Cetak Sawah, 2013: 19). 


\section{Keterangan}

Berdasarkan peta pada gambar 5, terjadi penyelewengan oleh pelaksana Proyek Cetak Sawah terhadap luasan land clearing tahap pertama. Disebutkan pada rencana awal, rencana Proyek Cetak Sawah sebesar 1010 Hektar, kemudian target proyek berkurang secara sepihak menjadi 865 Hektar. Namun, proyek berhenti dengan luas 562,7 Hektare.

Pada mulanya, proyek ini diusulkan Gapoktan kepada Pemerintah Kabupaten Ogan Komering Ilir sebelum bencana kebakaran 2015 terjadi. Akan tetapi, pemerintah hanya menyanggupi pengadaan cetak sawah seluas 300 Hektare. Usulan ini, berikutnya, dilanjutkan ke pemerintah pusat melalui kewenangan Dinas Pertanian hingga mendapatkan luasan 1010 Hektare. Pada Februari 2016, usai sosialisasi Cetak Sawah, terjadi simpang siur informasi terkait pembagian lahan. Di tengah keriuhan di kampung akibat Proyek Cetak Sawah, pada minggu pertama Mei 2016, dua ekskavator datang ke lokasi berladang Sonor. Namun, belum juga satu minggu bekerja, dua alat berat ini mogok. Banyak warga berseloroh, "alat berat itu belum dimintakan berkat dari dukun dan mereka lupa minta ijin kepada tuan tanah." Sebuah ungkapan yang menunjukkan ketidaksinambungan antara implementasi Proyek Cetak Sawah dengan petani penggarap perladangan Sonor. "Pembukaan lahan untuk cetak sawah ini bermasalah, karena orang yang datang tidak tahu cara mengolah gambut dan tidak berkomunikasi dengan petani yang tahu," ungkap Hadi Jatmiko, Direktur WALHI Sumatera Selatan. Proses land clearing dan manipulasi berita acara ini menujukkan inisiasi proyek yang berlangsung tidak transparan.

Bias kedua berkaitan dengan cara pandang Proyek Cetak Sawah terhadap realitas sosial Desa Talang. Di balik prosesnya yang berlangsung tidak transparan, perencanaan Proyek Cetak Sawah justru mengancam kerentanan petani penggarap yang hanya bisa mengakses lahan gambut untuk pertanian pangan. Akses terhadap lahan gambut menjadi satu-satunya jalan keluar saat lahan bertanah mineral sudah dimiliki secara legal oleh individu-individu petani perkebunan karet. Artinya, mereka yang hanya mampu mengakses lahan gambut untuk pertanian pangan merupakan buruh perkebun karet yang terlempar dari timpangnya hubungan agraria di tanah mineral.

Sejak kehadiran karet, masyarakat Desa Talang terbagi ke dalam relasi produksi pemilik tanah dengan buruh penyadap. Biasanya, para pemilik tanah akan mengupah saudara atau tetangganya yang tidak punya tanah untuk menyadap karet di kebun mereka. Upah buruh sadap diperoleh setiap tiga hari sekali, dengan nominal yang sangat bergantung pada hasil sadapan dan harga jual karet. Upah buruh sadap ini juga bergantung pada pemotongan pajak sebesar tiga kilogram yang diberikan kepada penampung, dengan alasan penampung harus membersihkan karet yang disadap. Seperti Ami, ia menyadap di atas tanah milik saudaranya. Setiap tiga hari, dia menjual hasil sadapan sekitar 70 sampai 80 kilogram ke penampung karet. Saat harga karet turun drastis dari 20.00o sampai 3.000 rupiah per kilogram, kemampuan untuk mencukupi pangan pun turun drastis. "Bila harga karet sampai 20.000 per kilogram, hasil ngangkit (menyadap) tiga hari bisa dipakai untuk satu bulan makan dan kebutuhan anak sekolah. Kalau sekarang susah," ungkap Ami.

Ami adalah salah satu perempuan dari banyak perempuan buruh sadap karet yang mengakses lahan garapan dari perladangan Sonor. Saat harga karet turun, maka, ladangladang Sonor menjadi sangat berharga. Berbeda dengan perkebunan karet di tanah mineral, luasan hak garap di atas ladang Sonor 
ditentukan kemampuan tenaga kerja produktif dalam rumah tangga tani mengerjakan lahan. Salah satunya ialah Heru yang memiliki lahan sampai 9 Hektare karena dikerjakan bersama anak-anaknya. Saat satu-satunya akses lahan garapan ini akan dibagi rata oleh pemerintah desa melalui Proyek Cetak Sawah, dia pun merasa keberatan. Menurutnya, jumlah tersebut sudah pas untuk diwariskan kepada anaknya yang ikut membuka ladang. Putusan terkait pembagian tanah ini berlangsung sepihak. Menurut Heru, "Bagaimana dengan orang yang tanahnya sembilan Hektare misalnya, adilkah menerima ganti hanya dua Hektare? Apa yang terjadi dengan anak-anak yang belum menikah?" Ia mengkhawatirkan salah satu anaknya yang belum menikah dan tidak ada dalam daftar penerima manfaat pembagian Lahan Cetak Sawah.

Bias ketiga, Proyek Cetak Sawah memiliki asumsi gender yang mengesampingkan realitas tentang curahan kerja petani perempuan di lahan gambut. Para perempuan tani ini memiliki pengetahuan tentang hubungan simbiosis mutualisme antara rumput purun rumput endemik di lahan gambut-dengan padi talang. Perempuan juga memiliki andil sangat besar dalam proses produksi perladangan Sonor, mulai dari menyebar benih sampai memanen.

Sebagai gambaran, pengalaman Nye Elok menunjukkanbahwaperempuanmenghabiskan waktu lebih panjang dibandingkan suaminya untuk bekerja di ladang Sonor. Menjelang fajar, para perempuan tani pergi ke kebun karet bersama suaminya. Suami dan istri menyadap karet bersama, sekaligus mengambil getah-getah yang sudah menetes di malam sebelumnya. Menjelang dhuhur, pasangan ini akan pulang ke rumah masing-masing untuk makan siang dan sholat. Bila di musim panen seperti Maret dan April 2016, seusai makan siang, para perempuan akan pergi kembali ke ladang untuk memanen dan kembali menjelang maghrib. Sembari mengunyah sirih, Nye Elok berujar, "perempuan di dusun ini bekerja dari pagi sampai dhuhur, misalnya ada pekerjaan di sawah ya mereka akan lanjut mengurus padi." Sementara para perempuan tani yang tidak memiliki kebun karet akan berangkat ke ladang Sonor setiap hari dari pukul enam pagi sampai matahari rebah. Di saat musim panen padi, satu Hektare ladang padi Sonor membutuhkan waktu dua sampai tiga bulan untuk bisa menyelesaikan panen. Pada musim ini, hampir semua orang mengerjakan panen padi di ladang masing-masing.

Padi-padi Sonor yang disebar oleh perempuan tani ini berlomba dengan rumput purun untuk tumbuh. Para perempuan, di samping mengurus padi, juga mengurus purun sampai menjadi anyaman. Kegiatan menganyam purun, dulunya, merupakan tradisi untuk mempertemukan lelaki dan perempuan di usia dewasa. Saat itu, gadisgadis akan duduk membelakangi lelaki bujang sembari menganyam purun. Disambut dengan lelaki bujang yang merapikan ujung anyaman. Cara ini menjadi tradisi untuk mereproduksi pengetahuan tentang anyaman purun. Perlahan, tradisi ini luntur. Para penganyam purun mulai kesulitan mewariskan pengetahuan tentang anyaman purun.

Meskipun curahan kerja di lahan gambut sebagai ladang garapan dekat dengan peran sosial perempuan, namun proses pengambilan keputusan atas lahan begitu timpang. Hal ini terlihat dari cerita tentang Proyek Cetak Sawah yang tidak pernah melibatkan perempuan dalam pertemuan-pertemuan penting. Akses informasi terkait Proyek Cetak Sawah hanya diperoleh dari cerita para suami, tetangga dan gossip di warung. Pertemuan formal bukan menjadi ruang bagi perempuan. Alhasil, Proyek Cetak Sawah berlangsung dengan menyisakan tanda tanya besar bagi perempuan. Terlebih 
saat mereka harus menemui kegagalan masa tanam di kampung.

Bias keempat, Proyek Cetak Sawah memiliki anggapan yang stigmatif terhadap praktik menebas dan membakar dalam penyiapan lahan. Bagi para pejabat pemerintahan, praktik Sonor dianggap sebagai satu-satunya penyebab kebakaran hutan dan lahan. Kondisi ini tidak ditempatkan dalam sejarah alih guna lahan ke perkebunan dan hutan tanaman industri skala besar. Stigma ini diinstrumentalisasi melalui serangkaian kebijakan kebakaran hutan dan lahan yang sudah berlangsung sejak masa Orde Baru sampai hari ini melalui peraturan daerah. Stigma ini cenderung menyudutkan pelaku kecil dan individual alih-alih kasus perusahaan besar sehingga rentan kriminalisasi petani perladangan Sonor.

Biasanya, petani penggarap melakukan perhitungan dalam mengatur waktu untuk berSonor. Bila air di lahan gambut sudah kering, pada waktu itulah warga membentuk barisan penjaga api untuk mulai membakar gambut, sejak awal Agustus sudah membersihkan lahan dan mulai membakar akhir Agustus. Hasil pembakaran lahan menjadi pupuk utama bagi perladangan Sonor. Menjelang akhir September, biasanya para petani penggarap sudah selesai menabur padi. Disela proses menabur benih padi sampai panen, tidak ada perawatan intensif lain selain memastikan padi tumbuh selama jeda menunggu panen.

Di sela menunggu padi inilah, rumput purun yang tumbuh secara liar di ladang padi Sonor bisa dimanfaatkan sebagai anyaman. Kelak, panen padi enam bulan kemudian akan dijemur di atas tikar purun. Pada saat panen, para perempuan di sekitar kampung memegang sungkur untuk meratakan padi. Di saat panen, perempuan tidak mengeluarkan biaya untuk menggiling padi. Saat padi dijemur, warga akan keluar ramai-ramai menginjak padi sekuat tenaga.

\section{Kesimpulan}

Proyek Cetak Sawah sebagai program pembangunan yang memobilisasi lahan skala besar ini belum mampu menjawab kebutuhan petani penggarap terhadap kecukupan pangan mereka. Sejak harga karet turun selama satu dekade belakangan, kebutuhan pangan tidak lagi tercukupi dari jual beli karet. Banyak petani penggarap memenuhi kebutuhan pangan dengan kembali berladang Sonor seperti nenek moyang mereka. Hanya saja, berladang Sonor menemui banyak halangan lantaran ekosistem pendukung di sekitarnya sudah terkepung konsesi perkebunan sawit dan hutan tanaman industri. Marjinalisasi negara terhadap sistem produksi perladangan ini semakin meningkat seiring kebakaran lahan yang kian intensif. Konteks inilah yang memungkinkan Proyek Cetak Sawah hadir. Hanya saja, proyek ini menyimpan empat bias yang memarjinalkan petani penggarap, terutama perempuan. Bias pertama berkaitan dengan implementasi proyek yang tidak transparan seiring kentalnya keterlibatan militer. Bias kedua berkaitan dengan cara pandang Proyek Cetak Sawah terhadap realitas sosial di Desa Talang yang menyingkirkan satu-satunya akses petani penggarap terhadap lahan gambut. Bias ketiga, Proyek Cetak Sawah memiliki asumsi gender yang mengesampingkan realitas tentang curahan kerja para petani perempuan di lahan gambut. Bias keempat, Proyek Cetak Sawah memiliki anggapan yang stigmatif terhadap praktik menebas dan membakar dalam penyiapan lahan.

\section{Ucapan Terimakasih}

Naskah ini, mula-mula, disusun sebagai kertas kerja Sajogyo Institute dengan menggunakan data kualitatif yang dikumpulkan oleh: Pertama, Aisa saat penelitian live in pada Februari 2016-Desember 2016. Terimakasih atas kesediaannya untuk 
mengikutsertakan data harian pada analisa naskah ini. Kedua, Ciptaningrat Larastiti dari beberapa kali kunjungan ke Palembang dan Ogan Komering Ilir Sumatera Selatan sekitar 2016-2017 serta komunikasi intensif dengan WALHI Sumatera Selatan. Proyek ini dilakukan atas kerjasama Sajogyo Institute, The Asia Foundation, dan WALHI Sumatera Selatan. Seluruh nama desa dan subyek penelitian sengaja penulis ganti dan proses analisa data menjadi tanggung jawab penulis.

\section{Daftar Pustaka}

Ant/L-8 2016, Program TNI AD Cetak Sawah Sembilan Provinsi. Suara Pembaharuan Online. http://sp.beritasatu.com/ home/program-tni-ad-cetak-sawahsembilan-provinsi/112888 diakses 27 Oktober 2016

Dove, Michael R 1994, "Transition from Native Forest Rubbers to Hevea Brasiliensis (Euphorbiaceae) among Tribal Smallholders in Borneo" dalam Economic Botany Vol. 48 No.4 382-396 .

Dove, Michael 2011, The Banana Tree at the Gate. Yale University Press

DPM-PTSP OKI 2016, Peluang dan Potensi. Dinas Penanaman Modal dan Pelayanan Terpadu Satu Pintu. http://bppm. kaboki.go.id/index.php/investasi/ peluang-dan-potensi diakses pada 14 Juni 2017

Fox, Jefferson., Yayoi Fujita, Dimbab Ngidang, Nancy Peluso, Lesley Potter, Niken Sakuntaladewi, Janet Sturgeon dan David Thomas 2009, "Policies, PoliticalEconomy and Swidden in Southeast Asia" dalam Human Ecology Vol. 37 Hal. 305-322

Hall, Derek., Philip Hirsch dan Tania Murray Li 2011, "Introduction" dalam Powers of Exclusion: Land Dilemas in Southeast Asia. Singapore: NUS Press
Jahansyahtono, Ramanda 2016, Mentan: 2016 Pemerintah Cetak Sawah Baru Lebih Banyak. Kompas.com. http://bisniskeuangan.kompas. com/read/2016/o1/o4/132215426/ Mentan.2016.Pemerintah.Cetak.Sawah. Baru.Lebih.Banyak diakses pada 12 Juni 2017

Letkol Inf Drs. Solih 2017, Peran Babinsa dalam Swasembada Pangan. TNI Angkatan Darat. http://tni.mil.id/view-112024peran-babinsa-dalam-swasembadapangan.html diakses pada 1 November 2017

Li, Tania M 2005, "Beyond "the State" and Failed Schemes" dalam American Anthropologist New Series Vol. 107 No. o3 Hal. 383-394.

Parliza, Hendrawan 2015, BencanaAsap, 612 Ribu Hektaree Hutan Terbakar di Sumatera Selatan. Tempo.co. https://m.tempo. co/read/news/2015/11/30/058723445/ bencana-asap-612-ribu-Hektareehutan-terbakar-di-sumatera-selatan diakses pada 13 juni 2017

Peluso, Nancy L., Peter Vandergeest 2001, "Genealogies of the Political Forest and Customary Rights in Indonesia, Malaysia, and Thailand" dalam The Journal of Asian Studies Vol. 6o No. 3 Hal. 761-812

Peluso, Nancy L., Peter Vandergeest 2006, "Empires of Forestry: Professional Forestry and State Power in Southeast Asia Part 1" dalam Environment and History Vol. 12 No. o1 Hal 31-64

Peluso, Nancy L., Peter Vandergeest 1995, "Territorialization and State Power in Thailand" dalam Theory and Society Vol. 24 No. 3 Hal. 385-426.

Potter, Lesley 1988, "Indigenous and Colonisers: Dutch Forest policy in South and East 
Borneo (Kalimantan) 1900 to 1950" dalam Changing Tropical Forest John Dargavel, Kay Dixon dan Noel Sempel (ed.). Canberra: Workshop Meeting Tropical History Working Group.

Dongoran, Hussein Abri., Mitra Tarigan., Istman M.P 2017, Proyek Pangan: Pelibatan TNItanpa Keputusan Presiden. Koran Tempo. https://koran.tempo.co/ $\mathrm{read} / 418033 /$ proyek-pangan-pelibatantni-tanpa-keputusan-presiden diakses pada Selasa 13 Juni 2017

Reid, Anthony 1984, “The Pre-Colonial Economy of Indonesia" dalam Bulletin of Indonesian Economic Studies Vol. 20 No. 2

Reid, Anthony 1995, "Humans and Forests in Pre-Colonial Southeast Asia" dalam Environment and History Vol. 1 Hal. 93110

Rosana, Doly 2017, Ogan Komering Ilir Sediakan 10.000 Hektare Restorasi Gambut. Antara Sumsel. http://sumsel.antaranews.com/ berita/31539o/ogan-komering-ilirsediakan-100oo-Hektaree-restorasigambut?utm_source=fly\&utm_ $\mathrm{med} \mathrm{i} \mathrm{u} \mathrm{m} \mathrm{=} \mathrm{re} \mathrm{la} \mathrm{te} \mathrm{d} \mathrm{\&} \mathrm{u} \mathrm{t} \mathrm{m}$ campaign=news diakses pada 5 Juni 2017

Rosana, Doly 2017, Sumsel Optimis Surplus Beras 2,7 Juta Ton. Antara Sumsel. http://sumsel.antaranews.com/ berita/311499/sumsel-optimistissurplus-beras-27-juta-ton Diakses pada 5 Juni 2017
Rosana, Dolly 2017, OKI Tawarkan Lahan 10.00o Hektare Jadi Sawah. Antara Sumsel. http://sumsel.antaranews. com/berita/31146o/oki-tawarkanlahan-10ooo-Hektaree-jadi-sawah diakses pada 5 Juni 2017

Scott, James C 1999, Seing Like A State: How Certain Schemes to Improve the Human Condition Have Failed. New Heaven dan London: Yale University Press

Tauchid, Mochammad 2009, Masalah Agraria: Sebagai Masalah Penghidupan dan Kemakmuran Rakyat Indonesia. Yogyakarta: STPN Press

Tsing, L. Anna 2005, The Friction: An Ethnography of Global Connection. New Jersey: Princenton University Press. 